\title{
New observations of alien foraminifera on the Turkish coasts of the Aegean Sea (2012-2015)
}

\author{
Engin MERIÇ⿻ ${ }^{1}$, M. Baki YOKEŞ ${ }^{2}$, Niyazi AVŞAR ${ }^{3}$, Feyza DİNÇER $^{4}$ \\ 1* Moda Hüseyin Bey Sokak No: 15/4, 34710 KADIKOY, ISTANBUL-TR \\ ${ }^{2}$ Haliç University, Faculty of Arts and Sciences, Department of Molecular Biology and Genetics, SISLI, ISTANBUL-TR \\ ${ }^{3}$ Çukurova University, Faculty of Engineering and Architecture, Department of Geological Engineering, 01330, SARICAM, \\ ADANA-TR \\ ${ }^{4}$ Nevşehir Hacı Bektaş Veli University, Faculty of engineering and Architecture, Department of Geological Engineering, \\ 50300, NEVSEHIR-TR
}

Corresponding author* Tel: +90 5323345893

Received 20 October 2015

E-mail: ienginmeric@hotmail.com

Accepted 30 December 2015

\begin{abstract}
During the benthic foraminiferal surveys conducted on the Aegean coasts of Turkey between 2012-2015, new alien species have been observed. These were either recent introductions, such as Cornuspiroides striolatus (Brady), Nodobaculariella cristobalensis McCulloch, N. galapagosensis McCulloch, Pseudonodosaria discreta (Reuss), Polymorphina fistulosa (Cushman) or south to north range expansions of the species previously known to inhabit Levant Basin, Cyclorbiculina compressa (d'Orbigny). Besides, Amphistegina lobifera Larsen which has been known to inhabit Kuşadası Bay and nothwestern coasts of Karaburun Peninsula has also been abundantly observed around Doğanbey Bay.
\end{abstract}

Warm submarine springs are suggested to be the main cause of these thermophilic species to settle and form stable populations on the Aegean cost of Turkey. On the other hand salinity variations may also help to the spreading of these aliens. Thus, it is suggested that new introductions may follow in the near future.

Keywords: Foraminifera, Turkish coasts, Diversity, Aegean Sea

\section{Introduction}

New records of alien species are continously being reported from the Mediterranean coasts. Most of the alien foraminifer species are IndoPacific originated and are introduced to eastern Mediterranean via Suez Canal. However, there are also some alien species recorded in the Aegean Sea, which are known from west Pacific and not found in the Red Sea fauna. Shipping via ballast waters is suggested to be the main way of intorduction for these species. Alien foraminifer records from the Aegean coasts between 20082011 have been reviewed by Meriç et al. (2016a). In this study new introductions and range expansions observed on the easter Aegean coasts (Figure 1) between 2012-2015 are reviewed.

\section{Alien species recorded on the Aegean coasts of Turkey between 2012-2015 (Figure 2):}

Northern Aegean Sea: Polymorphina fistulosa (Cushman) $\bullet$.

Gulf of Edremit: Nodobaculariella cristobalensis McCulloch $\diamond$.

Gulf of İzmir: Nodobaculariella cristobalensis McCulloch $\bullet, N$. galapagosensis McCulloch $\bullet$.

Ildır Bay: Cornuspiroides striolatus (Brady) $\star$.

Ilıca Bay (Çeşme): Polymorphina fistulosa (Cushman) $\bullet$.

Doğanbey Bay: Cyclorbiculina compressa (d'Orbigny) $\boldsymbol{\Delta}$ ve Amphistegina lobifera Larsen $\boldsymbol{0}$.

Akköy Bay: Pseudonodosaria discreta (Reuss)

Gulf of Güllük: Nodobaculariella cristobalensis McCulloch 


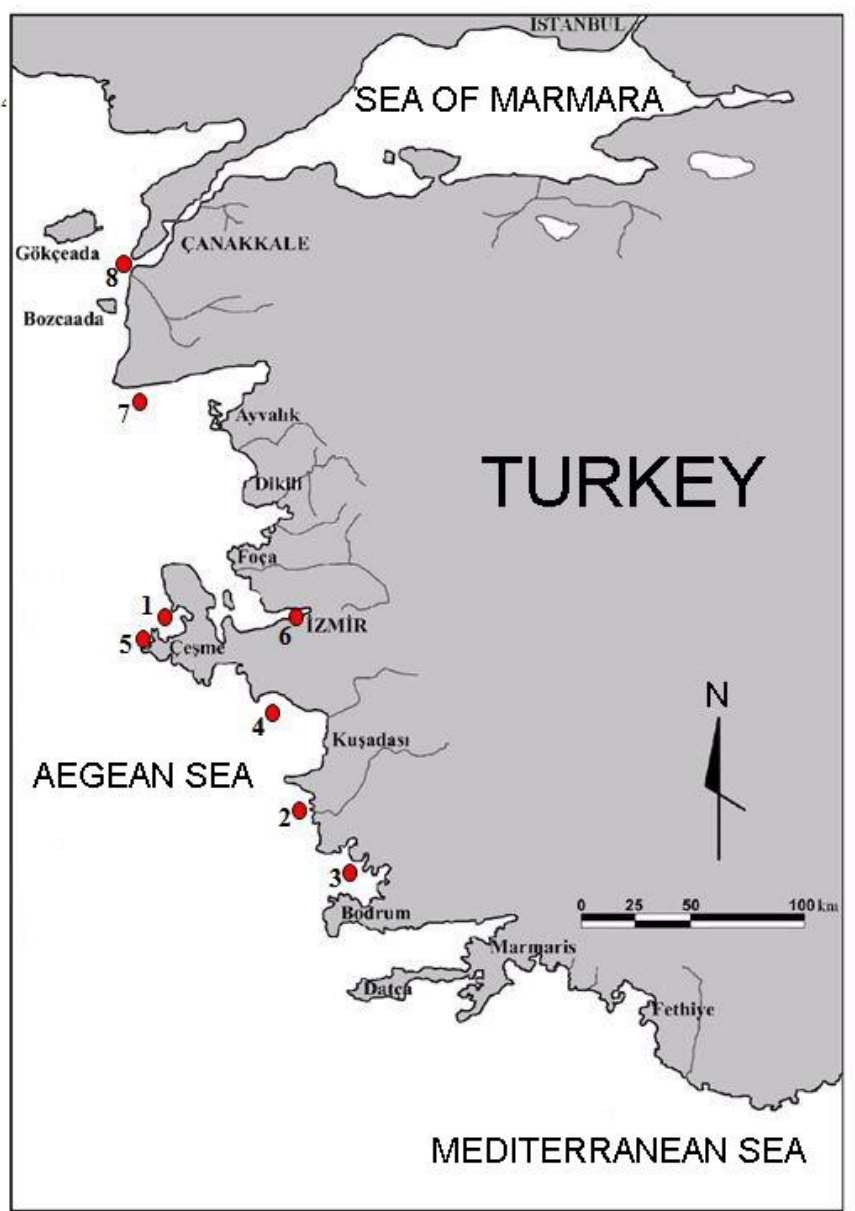

Figure 1. Study areas in the Eastern Aegen Sea. 1-Ildır Bay, 2-Akköy Bay, 3-Gulf of Güllük, 4Doğanbey Bay, 5- Ilıca Bay, 6-Gulf of İzmir, 7-Gulf of Edremit, 8- entrance of the Dardanelles.

\section{Findings}

A rich alien benthic foraminiferal fauna was observed on the Aegean coast of Turkey. These species were originated from Pacific Ocean, Atlantic Ocean and Red Sea.

Cornuspiroides striolatus (Brady) which has been abundantly observed in Ildır Bay, north of Karaburun Peninsula has been known to inhabit Timor Sea and New Caledonia, but has not been recorded neither in the Indian Ocean nor in the Red Sea (Meriç et al., 2016a).

Nodobaculariella cristobalensis McCulloch has been recorded in Gulves of Edremit, İzmir and Güllük, Nodobaculariella galapagosensis McCulloch has been recorded in Gulf of İzmir, indicating the presenc of special environmenatl conditions in these locations, since this species has not been recorded elsewhere in the Mediterranean Sea (Meriç et al., 2016a). Nodobaculariella cristobalensis McCulloch has been first recorded in Gulves of Güllük and İzmir. Thus, it is suggested that this species expanded its range of distribution northward to Gulf of Edremit in time. Warm submarine springs are considered to be the main vector in its dispersal.

The Red Sea originated Cyclorbiculina compressa (d'Orbigny) has been previously recorded along the coasts of Antalya (Meriç et al., 2008). It seems that this species has expanded its range of distribution up to Doğanbey Bay. Amphistegina lobifera Larsen 
which is widely distributed in the Levant Basin, has also been recorded in Gulf of Kuşadası and on the northwestern coasts of Karaburun Peninsula (Yokeş et al. 2012; Meriç et al., $2012 b$ ). Recently it is also found to be abundant im Doğanbey Bay (Meriç et al., 2016b).

In the literature Pseudonodosaria discreta (Reuss) is only known from Timor Sea. However this species is recently recorded in Ildir
Bay, which constitute its first record in the Mediterranean (Meriç etal., 2015).

An other recent observation is Polymorphina fistulosa (Cushman), which is Pacific originated and recorded from southwestern Dardanelles and Ilıca Bay (İzmir) (Meriç et al., 2012a). It has been previously identified as Polymorphina $s p$. in the Mediterranean, but not at the species level (Cimerman and Langer, 1991)

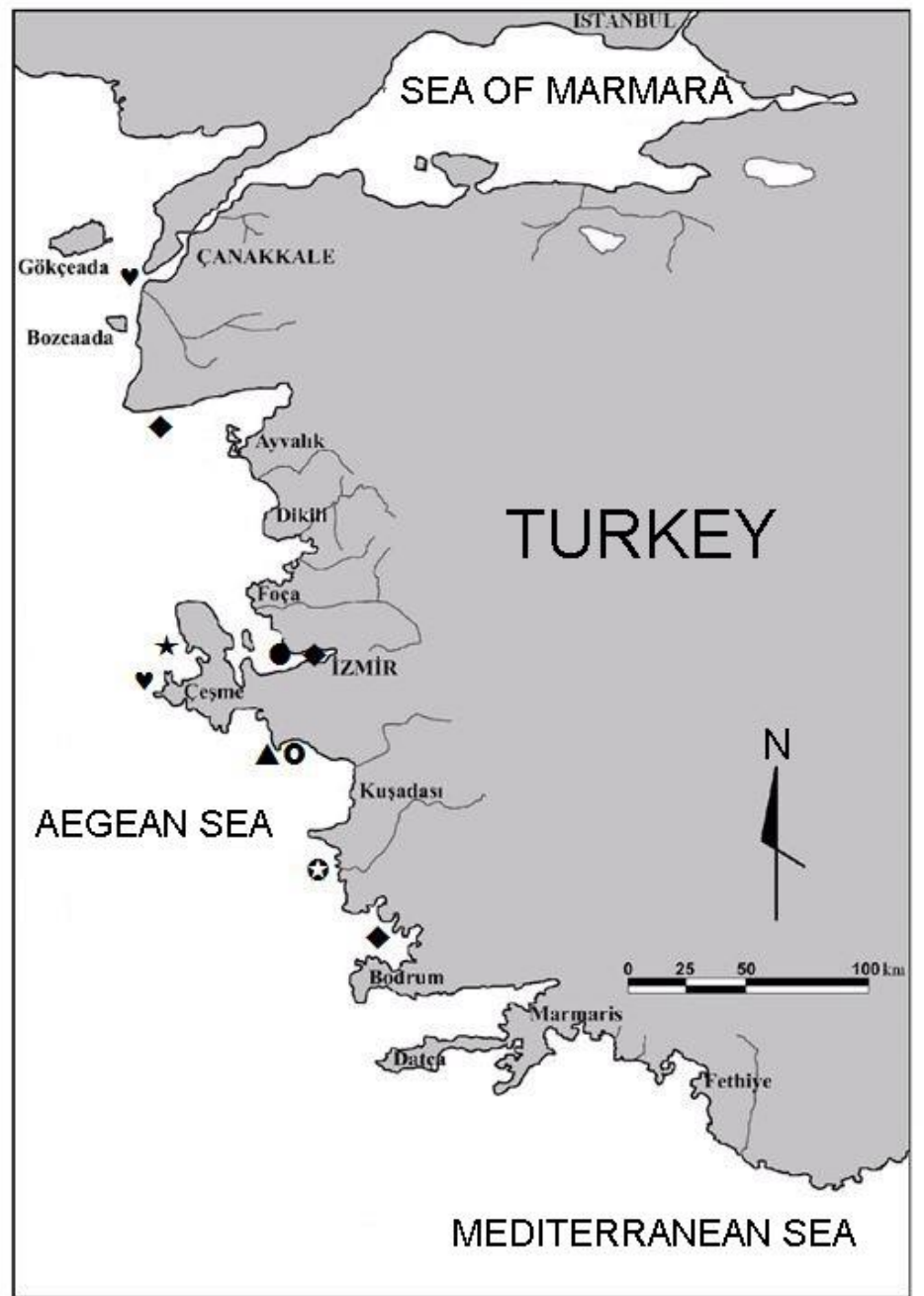

Figure 2. Distribution of newly recorded alien forminifer species in the Eastern Aegean Sea $\star$ Cornuspiroides striolatus (Brady), $\boldsymbol{\vee P o l y m o r p h i n a ~ f i s t u l o s a ~ ( C u s h m a n ) , ~} \boldsymbol{\Delta}$ Cyclorbiculina compressa (d'Orbigny), $\boldsymbol{\otimes}$ Peudonodosaria discreta (Reuss), $\diamond$ Nodobaculariella cristobalensis McCulloch, N. galapagosensis McCulloch, $\mathbf{0}$ Amphistegina lobifera Larsen. 


\section{REFERENCES}

Cimerman, F. and Langer,, M. R., 1991. Mediterranean foraminifera. Slovenska Akademija Znanosti in Umetnosti, Akademia Scientiarum et Artium Slovenica. 118 p., 93 plts., Ljubljana.

Meriç, E., Avşar, N. and Yokeş, B., 2008. Some alien foraminifers along the Aegean and southwestern coasts of Turkey. Micropaleontology, in: Recent benthic foraminifera along the southwest coasts of Antalya (SW Turkey) and the impact of alien species on authocthonous fauna (eds. E. Meriç and M. B. Yokeş), 54 (3-4), 307-349.

Meriç, E., Yokeş, M. B., Avşar, N., Kırc1-Elmas, E., Dinçer, F., 2012a. A new record in eastern Aegean Sea (Turkey): Polymorphina fistulosa. Marine Biodiversity Records, 5, e103, 1-3.

Meriç, E., Avşar, N., Nazik, A., Yokeş, B., Dora, Ö., Barut, İ., Eryılmaz, M., Dinçer, F., Kam, E., Aksu, A., Taşkın, H., Başsarı, A., Bircan, C., Kaygun, A., 2012b Karaburun Yarımadas1 Kuzey Kıyılarının Oşinografik Özelliklerinin Bentik Foraminifer ve Ostrakod Toplulukları Üzerindeki Etkileri . Maden Tetkik ve Arama Dergisi 145: 22-47.
Meriç, E., Yokeş, M. B., Avşar, N., Dinçer, F., 2015, New Observations of Alien Foraminifera on the Turkish Coasts of the Aegean Sea (20082011). International Journal of Environment and Geoinformatics 2(2): 77-87

Meriç, E., Yokeş, M. B., Avşar, N., Yümün, Z. Ü., Dinçer, F., 2016a, New alien foraminifer guests in eastern Aegean Sea (Turkey) (in preparation).

Meriç, E., Avşar, N., Nazik, A., Barut, İ. F., Yokeş, M. B., Eryılmaz, M., Kam, E., Sonuvar, B., Dinçer, F., 2016b, Doğanbey Burnu (Seferhisar-İzmir) sıcak su çıkışlarının çevresindeki foraminifer, ostrakod ve mollusk topluluğu hakkında (in preparation).

Yokes MB, Meriç E, Avşar N, Barut İ, Tas S, Eryilmaz M Dinçer F and Bircan C., 2014. Opinions and comments on the benthic foraminiferal assemblage observed around the mineral submarine spring in Kuşadası (Aydın, Turkey). Marine Biodiversity Records, 7: e103, doi:10.1017/S1755267214000840. 